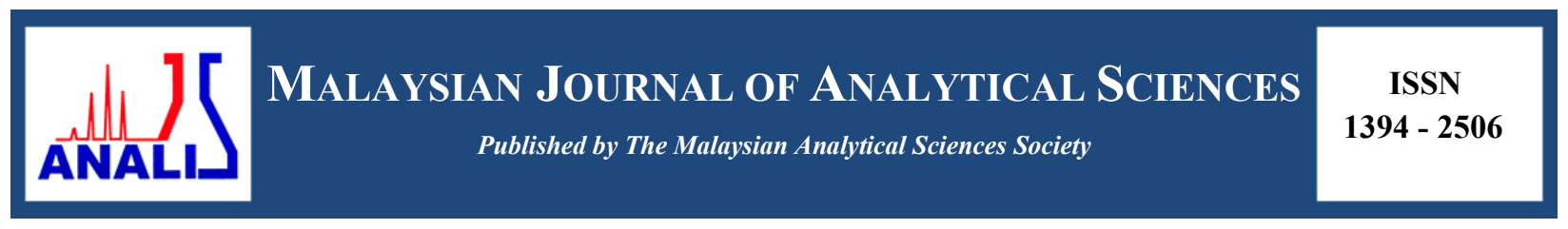

\title{
ADSORBENTS FROM THE BY-PRODUCT OF PALM OIL REFINERY FOR METHYLENE BLUE REMOVAL
}

\section{(Penjerap daripada Produk Sampingan Penapisan Minyak Sawit untuk Penyingkiran Metilena Biru)}

\author{
Hamzat Bashir Aderemi ${ }^{1,2}$, Muhammad Abbas Ahmad Zaini ${ }^{1,3 *}$, Noor Shawal Nasri ${ }^{3,4}$ \\ ${ }^{1}$ Centre of Lipids Engineering \& Applied Research, Ibnu-Sina Institute for Scientific \& Industrial Research \\ Universiti Teknologi Malaysia, 81310 UTM Johor Bahru, Johor, Malaysia \\ ${ }^{2}$ Chemical Engineering Department, \\ Kaduna Polytechnic, Kaduna, Nigeria \\ ${ }^{3}$ Faculty of Chemical \& Energy Engineering \\ ${ }^{4}$ UTM-MPRC Institute for Oil \& Gas \\ Universiti Teknologi Malaysia, 81310 UTM Johor Bahru, Johor, Malaysia \\ *Corresponding author: abbas@cheme.utm.my
}

Received: 16 April 2017; Accepted: 7 March 2018

\begin{abstract}
The present work was aimed at evaluating the removal of methylene blue by palm fatty acid distillate-based adsorbents. The adsorbents at different weight ratios of palm fatty acid distillate (PFAD) to palm kernel shell (PKS) were prepared at $600{ }^{\circ} \mathrm{C}$ for 2 hours. Results show that the yield of adsorbent upon heat treatment decreased with increasing weight ratio, with yield as low as $0.53 \%$ was recorded by adsorbent derived by using only PFAD. The methylene blue adsorption data show a promising performance of PFAD-based adsorbents as compared to that of PKS-adsorbent (char) with $q_{e}=7.6 \mathrm{mg} / \mathrm{g}$ at $C_{o}=20.8 \mathrm{mg} / \mathrm{L}$. To conclude, PFAD is a potential candidate of dye adsorbent.
\end{abstract}

Keyword: adsorbent, methylene blue, palm fatty acid distillate, palm kernel shell

Abstrak

Tujuan kajian ini adalah untuk menilai penyingkiran metilena biru oleh penjerap berasaskan distilat asid lemak sawit. Penjerap pada nisbah berat distilat asid lemak sawit (PFAD) kepada isirong sawit (PKS) disediakan pada $600{ }^{\circ} \mathrm{C}$ selama 2 jam. Keputusan menunjukkan bahawa hasil penjerap setelah rawatan haba berkurang dengan peningkatan nisbah berat, dengan hasil serendah 0.53\% direkodkan oleh penjerap terbitan PFAD sahaja. Data penjerapan metilena biru menunjukkan prestasi menjanjikan oleh penjerap berasaskan PFAD berbanding penjerap berasaskan PKS (arang) dengan $q_{e}=7.6 \mathrm{mg} / \mathrm{g} \mathrm{pada} C_{o}=20.8 \mathrm{mg} / \mathrm{L}$. Kesimpulannya, PFAD ialah calon berpotensi sebagai penjerap pencelup.

Kata kunci: penjerap, metilena biru, distilat asid lemak sawit, isirong sawit

\section{Introduction}

There has been an increasing interest to valorize industrial waste into value added commodity [1]. Waste that is high in carbon content is a promising candidate of carbonaceous char that can be further processed into porous adsorbent for wide range of applications in water and wastewater treatment. A promising candidate under this category is palm fatty acid distillate (PFAD) [2]. PFAD is a by-product of crude palm oil refining process. At room temperature it is in light brown, semi-solid form, and melts as brown liquid upon heating. PFAD comprises mainly of free fatty acid 
(about 80\%), in which palmitic acid and oleic acid are the major components, while the remainders are triglycerides, partial triglycerides and unsaponifiable matters [3].

PFAD is cheap and abundantly available [4]. It is generally used in low-grade soap, animal feed, and other oleochemical products such as candles, cosmetics and toiletries. Because of its substandard quality, PFAD is not usually blended and capitalized in high-end products. Hence, there is a need to exploit the inherent benefits associated with this by-product. Therefore, the present work was aimed at evaluating this material as adsorbent precursor for methylene blue adsorption.

\section{Materials and Methods}

Palm fatty acid distillate (PFAD) was supplied by IFFCO (M) Sdn Bhd. Palm kernel shell (PKS) was obtained from a local palm oil mill. PFAD and PKS were used as received. Methylene blue dye powder $\left(\mathrm{C}_{16} \mathrm{H}_{18} \mathrm{ClN}_{3} \mathrm{~S}\right.$, molecular weight $=319.85 \mathrm{~g} / \mathrm{mol}$, assay $98.5 \%$ ) was supplied by HmbG Chemicals. The chemical structure of methylene blue is shown in Figure 1.

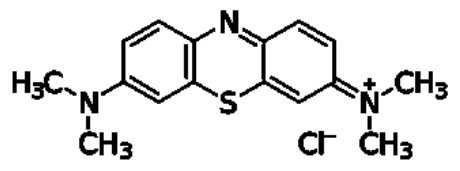

Figure 1. Molecular structure methylene blue

PFAD was mixed with PKS at different weight ratios (PFAD: PKS) of 2, 4, 5, 10 and 20. Then, the solid mixture was heated in furnace at $600{ }^{\circ} \mathrm{C}$ for 2 hours. The process is also known as carbonization. The same procedure was repeated for individual PFAD (0.5 hour) and PKS, respectively. All resultant adsorbents were used for methylene blue adsorption.

The working solution of desired methylene blue concentrations was prepared by diluting the stock solution. Thirty milligrams of solid adsorbent was brought into intimate contact with $30 \mathrm{~mL}$ of methylene blue solution of different concentrations. The solution mixture was allowed to equilibrate for 72 hours. After that, the residual concentration was measured using visible spectrophotometer (Halo Vis-10) at a wavelength of $615 \mathrm{~nm}$. The adsorption capacity, $q_{e}(\mathrm{mg} / \mathrm{g})$ was calculated using equation 1 :

$$
q_{e}=\left(C_{o}-C_{e}\right) \times V / m
$$

where $C_{o}$ and $C_{e}(\mathrm{mg} / \mathrm{L})$ are the initial and equilibrium concentrations, respectively, $V(\mathrm{~L})$ is the volume of methylene blue solution, and $m(\mathrm{~g})$ is the weight of solid adsorbent.

\section{Results and Discussion}

Table 1 shows the yield of adsorbents derived from PFAD and PKS. The yield decreased from $10.6 \%$ to $0.53 \%$ with increasing PFAD-to-PKS ratio. It implies the oxidative effect of PFAD towards PKS, whereby PFAD in the presence of PKS could act as the oxidizing agent. The higher the amount of PFAD the more aggressive the oxidation process, consequently, the greater the weight loss. The role of PFAD is analogous to $\mathrm{KOH}$, a commonly used activating/oxidizing agent for activated carbon preparation [5]. In the absence of PKS, PFAD displays a lower yield of $0.53 \%$ compared to $30 \%$ for only PKS (char) after the heat treatment. This signifies the feasibility of converting semi-solid PFAD into carbon-rich solid material and a promising adsorbent candidate although the yield is comparatively small. PKS alone exhibits a $30 \%$ yield. In the absence of activating agent, the carbonization of PKS at $600{ }^{\circ} \mathrm{C}$ normally produces rudimentary and partially clogged pores with undeveloped texture $[6,7]$. 
Table 1. Yield of adsorbents derived from PFAD and PKS

\begin{tabular}{ccc}
\hline Sample ID & PFAD-to-PKS ratio & Yield (\%) \\
\hline $\mathrm{C}_{1}{ }^{\mathrm{a}}$ & Only PFAD & 0.53 \\
$\mathrm{C}_{2}$ & 2 & 10.6 \\
$\mathrm{C}_{3}$ & 4 & 6.18 \\
$\mathrm{C}_{4}$ & 5 & 5.34 \\
$\mathrm{C}_{5}$ & 10 & 3.0 \\
$\mathrm{C}_{6}$ & 20 & 2.0 \\
$\mathrm{C}_{7}$ & Only PKS & 30 \\
\hline
\end{tabular}

${ }^{\text {a }}$ Pyrolysis at $600{ }^{\circ} \mathrm{C}$ for 0.5 hour

Figure 2 shows the removal of methylene blue by PKS- and PFD-derived adsorbents. All adsorbents demonstrate an increasing pattern of adsorption capacity with increasing methylene blue concentration. The concentration gradient is generally viewed as the driving force to overcome the adsorbent mass transfer resistance. The higher the solute concentration, the greater the adsorption capacity until the surface saturation is reached. In general, the adsorption of methylene blue onto adsorbent involved four steps. The first step is the liquid phase mass transfer in which the dye molecules shift from the bulk solution to the outer surface of adsorbent. This is followed by a second step that is diffusion of dye molecules through the interface surrounding the adsorbent (external diffusion step). The third step is the adhesion of dye molecules onto the active sites located on the outer layer of adsorbent (adsorption step). Finally, the fourth step is the intra-particle diffusion of dye molecules through the pores of adsorbents. In the adsorption-related wastewater treatment, the mass transfer step is considered as the rate determining process since the dye molecules adsorb onto active sites in a slow manner [8].

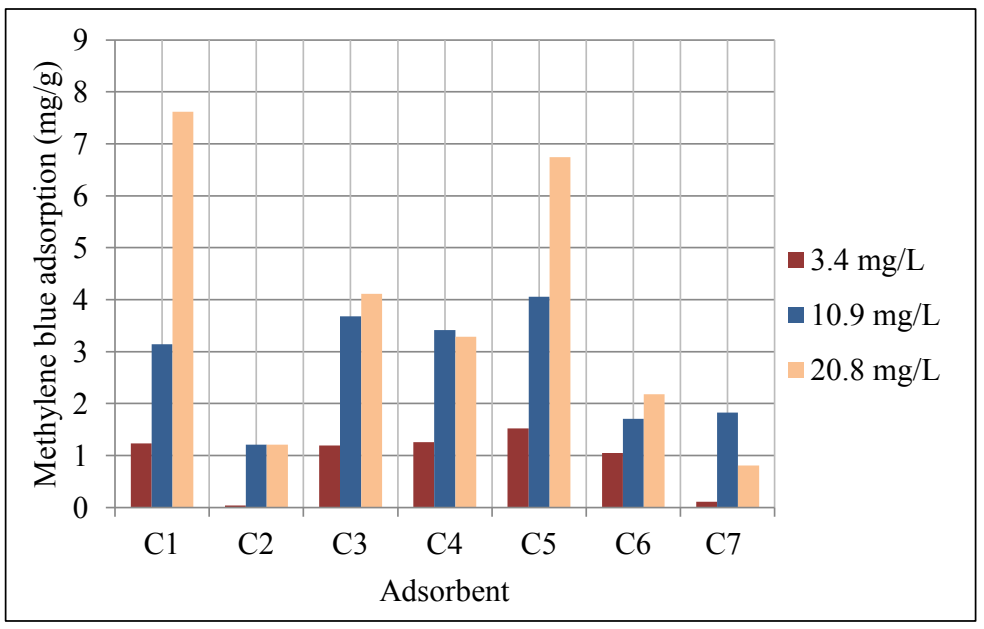

Figure 2. Methylene blue removal by adsorbents

Adsorbent derived from PFAD alone exhibits a better adsorption of methylene blue with $q_{e}=7.6 \mathrm{mg} / \mathrm{g}$ at $C_{o}=20.8$ $\mathrm{mg} / \mathrm{L}$, compared to that prepared from PKS alone. It shows a good prospective of PFAD as adsorbent precursor or activating agent. This is true when compared with other PFAD-PKS mixed adsorbents as displayed in Figure 2. For adsorbents prepared at different PFAD-to-PKS ratios, $\mathrm{C}_{5}$ (ratio 10) demonstrates a higher methylene blue removal, that is somewhat comparable to that of $\mathrm{C}_{1}$. A bell-shaped distribution of adsorption capacity shown by $\mathrm{C}_{2}$ to $\mathrm{C}_{6}$ supported the comparability that PFAD can act as oxidizing agent, and most likely as an activating agent too for PKS. This pattern indicates the development of solid porous texture as the ratio of PFAD increases. However, 


\section{Aderemi et al: ADSORBENTS FROM THE BY-PRODUCT OF PALM OIL REFINERY FOR METHYLENE} BLUE REMOVAL

beyond the optimum point, the porous texture starts to collapse due to the broadening of existing pores because of excessive oxidizing/activating agent [5,9]. Nevertheless, more in-depth physico-chemical characterization of adsorbents would be needed as future works to confirm and establish the present findings.

Adsorption isotherm is crucial in comprehending the concept of adsorptive molecular distribution between the solid phase and the liquid phase at equilibrium. Equilibrium is attained when the rate of adsorption is equal to the rate of desorption for a given concentration. The fitting of experimental data into isotherm models is an indispensable step to analyze the adsorption behaviour for design purposes. The adsorption data were analyzed using two commonly used models, namely Langmuir and Freundlich equations [10,11].

The Langmuir model assumed monolayer coverage of adsorbate over a surface that holds a limited number of adsorption sites of uniform adsorption energy with no transmigration of adsorbate in the plane of surface. All sites are identical and energetically equivalent, and the adsorbent is structurally homogeneous. At surface saturation, no further adsorption can take place with increasing concentration, thus giving rise to the formation of a plateau graphically which also indicates a maximum adsorption capacity. The linearized form of Langmuir isotherm is expressed as equation 2:

$$
C_{e} / q_{e}=1 / Q_{m} b+C_{e} / q_{e}
$$

where $b(\mathrm{~L} / \mathrm{mg})$ is the Langmuir isotherm constant and $Q_{m}(\mathrm{mg} / \mathrm{g})$ is the maximum monolayer coverage. By plotting $C_{e} / q_{e}$ against $C_{e}$, the values of $b$ and $Q_{m}$ can be numerically determined from the gradient and y-intercept.

The Freundlich model assumed multilayer adsorption process on a heterogeneous surface. This isotherm model involves an exponential term of equilibrium concentration, suggesting that the adsorbate concentration on the adsorbent surface $\left(q_{e}\right)$ increases exponentially along with the adsorbate concentration $\left(C_{e}\right)$ in the solution. The linear form of Freundlich equation is given in equation 3:

$$
\log q_{e}=\log K_{F}+(1 / n) \log C_{e}
$$

where $K_{F}$ is the Freundlich constant related to the adsorption capacity and $n$ is the adsorption intensity. A straight line can be elicited by plotting $\log q_{e}$ against $\log C_{e}$ to determine $K_{F}$ and $n$. The surface heterogeneity or adsorption strength can be suggested using the gradient ranging between 0 and 1 . The adsorption is more heterogeneous if the value is near to zero. The value which is less than 1 suggests the chemisorption process, while that of more than one implies the cooperative adsorption.

The Langmuir and Freundlich constants of methylene blue adsorption onto PKS and PFAD derived adsorbents are summarized in Table 2. The coefficient of determination, $\mathrm{R}^{2}$ of 0.90 or greater reflects the acceptable fitting of Langmuir model with the adsorption data. The applicability of Langmuir model suggests that the adsorption of methylene blue onto the prepared adsorbents is monolayer and occurs over a surface with homogeneous energy sites accessible for interaction $[12,13]$. Adsorbents $\mathrm{C} 1, \mathrm{C} 3, \mathrm{C} 4, \mathrm{C} 5$, and $\mathrm{C} 6$ gave $\mathrm{R}^{2}$ values greater than 0.90 , while that of $\mathrm{C} 2$ and $\mathrm{C} 7$ are lesser than 0.90 . This could be associated with the poor removal performance of the latter adsorbents. Also, the calculated $Q_{m}$ values are relatively close to the experimental ones (Figure 2).

The adsorption data were not adequately fitted to the Freundlich model as the $\mathrm{R}^{2}$ values are lower, i.e. between 0.002 and 0.551 (Table 2). This implies that the model could not in any way be used to describe the methylene blue adsorption onto the adsorbents derived from PFAD, PKS and mixtures of both. The $n$ constant supplies important information on the heterogeneous factor of the adsorbent which suggests that the adsorption system is linear when $n$ $=1$, chemical-type $(n<1)$ or physical-type $(n>1)$. Similarly, the adsorption intensity or the surface heterogeneity can be evaluated using $1 / n$, whereby the surface is more heterogeneous when $1 / n$ value approaches zero. Here, the $1 / n$ values ranging from 0.0002 to 0.981 indicating the high surface heterogeneity of the adsorbents. While the corresponding $n$ values signify that the process could be of physical-type adsorption (physisorption). However, this is somewhat in contradiction with the underlying notion of Langmuir model which stated that the process could be of chemical-type adsorption (chemisorption). The possible mechanisms of chemical-type adsorption between 
methylene blue molecules and adsorbent surface include $\pi-\pi$ interaction, $\pi$-cation interaction and the roles of acidic functional groups [14].

Table 2. Isotherm constants

\begin{tabular}{|c|c|c|c|c|c|c|}
\hline \multirow{2}{*}{ Adsorbent } & \multicolumn{3}{|c|}{ Langmuir isotherm } & \multicolumn{3}{|c|}{ Freundlich isotherm } \\
\hline & $Q_{m}(\mathrm{mg} / \mathrm{g})$ & $b(\mathrm{~L} / \mathrm{g})$ & $\mathbf{R}^{2}$ & $K_{F}(\mathrm{mg} / \mathrm{g})(\mathrm{L} / \mathrm{mg})^{1 / n}$ & $1 / n$ & $\mathbf{R}^{2}$ \\
\hline $\mathrm{C} 1$ & 5.87 & 0.461 & 0.989 & 1.314 & 0.369 & 0.551 \\
\hline $\mathrm{C} 2$ & 3.08 & 0.0079 & 0.039 & 0.235 & 0.981 & 0.470 \\
\hline $\mathrm{C} 3$ & 1.11 & 0.282 & 0.978 & 1.41 & 0.0002 & 0.002 \\
\hline $\mathrm{C} 4$ & 0.108 & 0.179 & 0.958 & 1.65 & 0.517 & 0.336 \\
\hline $\mathrm{C} 5$ & 2.76 & 0.656 & 0.994 & 1.53 & 0.140 & 0.214 \\
\hline C6 & 0.550 & 0 & 0.929 & 1.23 & 0.132 & 0.115 \\
\hline $\mathrm{C} 7$ & 0.970 & 0.106 & 0.805 & 0.467 & 0.490 & 0.261 \\
\hline
\end{tabular}

\section{Conclusion}

Adsorbents were prepared using palm fatty acid distillate (PFAD) and palm kernel shell (PKS) at varying PFAD-toPKS ratios. Adsorbent derived from PFAD alone shows a promising removal performance of methylene blue compared to PKS alone (char) even though the yield of the former is small. The removal of PFAD-based adsorbent was recorded as $q_{e}=7.6 \mathrm{mg} / \mathrm{g}$ at $C_{o}=20.8 \mathrm{mg} / \mathrm{L}$. PFAD may act as oxidizing agent and activating agent in the presence of PKS. As such, the adsorbents produced display a bell-shaped distribution of adsorption capacity that is analogous to $\mathrm{KOH}$ activation. The adsorption data fitted well into Langmuir isotherm, suggesting monolayer coverage of methylene blue molecules, uniformly distributed onto homogeneous adsorbent surface. Also, the process could be that of chemisorption. The present findings concluded that PFAD is a promising candidate of dyes adsorbent.

\section{Acknowledgement}

Authors are grateful for the financial support by UTM-Flagship grants No. 03G70 and 14H19.

\section{References}

1. Garlapati, V. K., Shankar, U. and Budhiraja, A. (2016). bioconversion technologies of crude glycerol to value added industrial products. Biotechnology Reports, 9: 9-14.

2. Mahmood, W. M. F. W., Ariffin, M. A., Harun, Z., Ishak, N. A. I. Md., Ghani, J. A. and Rahman, M. N. Ab. (2015). Characterisation and potential use of biochar from gasified oil palm wastes. Journal of Engineering Science and Technology, 6: 45-54.

3. Ping, B. T. Y. and Yusof, M. (2009). Characteristics and properties of fatty acid distillates from palm oil. Oil Palm Bulletin, 59: 5-11.

4. Top, A. G. M. (2010) Production and utilization of palm fatty acid distillates (PFAD). Lipid Technology, 22(1): 11-13.

5. Shu-Hui, T. and Zaini, M. A. A. (2015). Potassium hydroxide activation of activated carbon: A commentary. Carbon Letters, 16(4): 275-280.

6. Zaini, M. A. A., Mohd-Setapar, S. H., Kamaruddin, M. J. and Yunus, M. A. C. (2013). In-depth studies of cattle-manure-compost activated carbons for $\mathrm{Cu}(\mathrm{II})$ ions removal. Agricultural Research Updates, 6: $247-265$.

7. Hamza, U. D., Nasri, N. S., Amin, N. S., Mohammed, J. and Zain, H. M. (2016). Characteristics of oil palm shell biochar and activated carbon prepared at different carbonization times. Desalination and Water Treatment, 57(17): 7999-8006.

8. Pezoti Jr., O., Cazetta, A. L., Souza, I. P. A. F., Bedin, K. C., Martins, A. C., Silva, T. L. and Almeida, V. C. (2014). Adsorption studies of methylene blue onto $\mathrm{ZnCl}_{2}$-activated carbon produced from buriti shells (Mauritia flexuosa L.). Journal of Industrial and Engineering Chemistry, 20(6): 4401-4407. 
9. Zaini, M. A. A., Okayama, R. and Machida, M. (2009). Adsorption of aqueous metal ions on cattle-manurecompost based activated carbons. Journal of Hazardous Materials, 170(2-3): 1119-1124.

10. Langmuir, I. (1918). The adsorption of gases on plane surfaces of glass, mica and platinum. Journal of American Chemical Society, 40(9): 1361-1403.

11. Freundlich, H. M. F. (1906). Over the adsorption in solution. The Journal of Physical Chemistry, 57: 385-470.

12. Zhi, L. L. and Zaini, M. A. A. (2017). Adsorption properties of cationic rhodamine B dye onto metals chlorideactivated castor bean residue carbons. Water Science and Technology, 75(4): 864-880.

13. Shu-Hui T. and Zaini, M. A. A. (2017). Malachite green adsorption by potassium salts-activated carbons derived from textile sludge: Equilibrium, kinetics and thermodynamics studies. Asia-Pacific Journal of Chemical Engineering, 12: 159-172.

14. Zaini, M. A. A. and Mohamad, N. A. (2015). Activated charcoal for oral medicinal purposes: Is it really activated? Journal of Applied Pharmaceutical Science, 5(10): 157-159. 